\title{
Hegemonic Project and the Protection of Migrant Workers in ASEAN
}

\author{
Edithea Steff Lapian ${ }^{1}$; Ismi Dwi Astuti Nurhaeni ${ }^{2}$; Mahendra Wijaya ${ }^{2}$ \\ ${ }^{1}$ Master Student of Sebelas Maret University, Indonesia \\ ${ }^{2}$ Department of Social and Politics, Sebelas Maret University, Indonesia \\ http://dx.doi.org/10.18415/ijmmu.v8i8.2842
}

\begin{abstract}
This article introduces hegemonic projects and the protection of migrant workers in ASEAN. We argue that the hegemonic project of the integration of ASEAN constituted through the protection of migrant workers. In this article, we evaluate how hegemonic discourse operated through the protection of migrant workers in ASEAN. The discourse on the protection of migrant workers in the ASEAN Consensus is thus instrumental to the operations and existence of the hegemonic project.
\end{abstract}

Keywords: ASEAN; Migrant Workers; Hegemony; Discourse

\section{Introduction}

Integration in the Southeast Asia region is made within the framework of the ASEAN Community, that is to make ASEAN an integrated regional organization in political, economical, and socio-cultural dimensions. This ASEAN Community emerged as the ASEAN Vision 2020, otherwise known as ASEAN Vision 2020. But in the ASEAN Summit in Cebu, the Philippines in 2007, ASEAN member countries agreed to accelerate the ASEAN Community from the plan in 2020 to 2015. The acceleration of the ASEAN Community in 2015 was based on considerations, (1) strengthening ASEAN's competitiveness in facing global competition, such as with India and China; (2) there is a potential to reduce production costs in ASEAN by 10-20 percent for consumer goods as a result of economic integration; (3) to enhance the capacity of the ASEAN region by implementing international standards and practices; (4) to align the targets for achieving the 2015 Millennium Development Goals (Ministry of Foreign Affairs, 2016: 28).

According to Moenir (2014), the establishment of the ASEAN Community is important to facilitate cooperation between the Member States in achieving organizational goals, such as strengthening and stability of integration in ASEAN. In the midst of the diversity of the Southeast Asian region, a sense of 'we-feeling, mutual respect, and high social solidarity within ASEAN, is one of the keys to the success of ASEAN integration; creating a caring and sharing community (Cebu Declaration, 2012).

Regional integration itself is a process where countries try to remove obstacles that hinder the interaction of relations between countries and form a regional space that is subject to some common rules (Best \& Christiansen, 2011). In the process of regional integration, according to Glarbo (Jackson \& Sorensen, 2014), there is an interaction, especially between political elites, communicating ideas about the purpose of political cooperation at the regional level in accordance with the national interests of each 
country. In practice, the interaction process often involves the construction of ideas from the dominant one. Actors who have power can then influence other actors to act and making decisions (Barnett, 2011). According to the concept of hegemony, the combination of coercion and consent from actors has the power, allowing the moral, cultural, and political values of the dominant group to spread widely in society, which is accepted by community groups, subordinates as their own moral, cultural, and political values (Hobden \& Jones, 2011). According to Cox (Barnett, 2011), the international system has shaped the world order in accordance with their (dominant) interests. On the other hand, hegemonic power also has a role in maintaining stability and progress at the domestic, regional, and international levels (Nur, 2017).

Labor migration is the main key to economic improvement in ASEAN countries, both for sending countries (countries of origin) obtained from remittances, and recipient countries (destination countries). According to Oliver (2018), labor migration is the impact of regional cooperation and economic integration that facilitates the movement of the flow of goods and services in the Region. After the integration was agreed upon and formed as the ASEAN Community, issues concerning migrant workers were included in the framework of ASEAN Community development. In the region, according to Human Rights Working Group (HRWG) Indonesia report, more than half of all migrant workers experience labor rights abuses during employment. ASEAN then agreed to The ASEAN Consensus on the Protection and Promotion of Rights of the Migrant Workers (later called by the ASEAN Consensus), formed in 2017 as an instrument for the protection of migrant workers. This is also for the implementation of the ASEAN Declaration on the Protection and Promotion of the Rights of Migrant Workers in 2007 or better known as the Cebu Declaration.

This study then tries to discuss the hegemonic project in the ASEAN Consensus as one of the steps of ASEAN integration in the ASEAN Community; how hegemonic discourse operates through the protection of migrant workers? To answer these questions, this paper uses a post-structuralism view of discourse and the concept of hegemony.

\section{Theory and Concept}

\section{The Theory of Post-structuralism}

This Post-structuralist theory appears to criticize the thinking of Structuralist theory. 'Language' is still the rationale of this Post-structuralism theory, but it is different from Structuralist, that according to Barker (2005) they try to critic the 'language' itself. Post-structuralist scholars believe that language is essential to understanding the world; there are implications of the view of language which is the basis of the human intellectual system (Hansen, 2011; Barry, 2002). In this regard, Hansen (2011) mentions that language is something social because it is a set of shared codes, where words or signs will have meaning (or make sense) when these words are connected to one another.

The concept of discourse is one of the concepts put forward by post-structuralist thinkers. This concept was developed by the French philosopher, namely Michel Foucault. Foucault (Hansen, 2011) argues that the language system regulates concepts and statements, where words that are used every day to describe something are not something "neutral", but have implications. politics is involved. For Foucault, discourse shapes the world, shapes knowledge and "truth", tells something about the person speaking, and gives power(Whisnant, 2012). Foucault wants to show that discourse can regulate certain social and cultural conditions. The ability to regulate these aspects of life is what Foucault calls power relations. He argues that power plays a role in generating coercion, growing and giving order (Barker, 2005). Foucault's conception of power itself is not merely a repressive action but also productive (Hansen, 2011). Kristeva (ibid.) makes an analogy when the state and institutions govern to establish themselves as knowing to manage a particular problem, it is an example of power. 
In this article, post-structuralist theory is used with the concept of discourse to explore how meaning operates in social practice through power, which is regulated in a discourse; namely the meaning of the ASEAN Consensus as a Regional instrument in the protection of migrant workers.

\section{The Concept of Hegemony}

Hegemony is defined as a combination of coercion and consent (Baylis, et al, 2011). This concept can be seen as an extension of the concept of power by Machiavelli. Power was originally defined as the ability that can force a person or group of people to do something they do not want. However, Foucault sees that power is not just an ability possessed to oppress and limit individuals, but sees power as equal to production; of identities and interests, resulting in forms and habits (Mills, 2003; Barnett, 2011). Many factors can support a power, such as area and population size, economy, political stability, military and security, available resources, technology, and knowledge (Waltz, 1979; Mills, 2009).

Hobden and Jones (Baylis, et al, 2011) explain that Gramsci's reading of Hegemony lies in the ruling class in society, by allowing the moral, political, and cultural values of the dominant group to spread through society which is accepted by the existing subordinate group or class. Along with the development of science, the conception of hegemony is also developed into various theories in International Relations. In general, Norrlof (Schmidt, 2018) sees hegemony in International Relations as a greater ability and capacity possessed by actors to shape the international system through coercion and or vice versa. On the same hand, Patria and Arief (2015) argue that hegemony shows the totality of leadership and domination.

According to Weber, domination is based on interests, and domination is nothing but a combination of power and legitimacy (Scott, 2007; Scott, 1990). Scott (2007) has the view that power becomes domination when power is articulated into a stable and binding controlling structure so that it can control over other agents or groups of agents. Morgan (Henk, 1993) argues that when the distribution of power is not balanced in a political system, then the system is an instrument of domination. Ideas or ideologies can be a source of domination for individuals or groups in providing legitimacy to power. The idea in general relates to the question of how beliefs and concerns related to the interests of certain social groups become public beliefs and concerns, and how they can impact social life (Fairclough \& Fairclough, 2012).

According to Howarth(Wullweber, 2018) the hegemonic strategy constructs a discourse or project, or stabilizes the structure of a hegemonic discourse or project. A hegemonic project can be interpreted as the existence of a main actor to promote certain normative by tying universal claims (together) with other actors, and realizing a certain vision of order (Friedrichs, 2005). Furthermore, according to Wullwiber (2018) hegemonic projects are formed on systematic power relations, prioritizing certain ways of knowing, being and acting, and only broadcasting experiences and agendas of certain actors in institutions, communities, or political entities. Process, practice, and discourse become the way for this hegemonic project.

\section{Result and Discussion}

\section{The Protection on Migrant Workers Make Hegemony Possible}

This part wants to discussed bout hegemonic project, in which integration in ASEAN Community will see from how hegemonic discourse operate through the protection on migrant workers. In other words, what can the tell us about ways in which discourse and practice of the ASEAN rely upon protection on migrant workers to enact and wield power.

Migration is perceived as an issue to act upon to enhance regional cooperation, that is to encourage to assist vulnerable migrants, to stimulate global partnership and also combat human trafficking and smuggling. Labor migration also contributes to the development of destination countries by filling labor 
market gaps, by providing essential skills and by bringing social, cultural and intellectual dynamism to migrant workers' destination countries (Cholewinski, 2013). The treatment of migrant workers in the ASEAN according to Srinivas \& Sivaraman (2011) still leaves much to be desired, more specifically in the economic and political context. For economic reasons as businesses in receiving countries want to spend as little on labour as possible. Another reason in political, as government worry about how domestic populations would respond to large influxes of migrant workers from the neighbour countries.

The protection on migrant workers, as conceived in the ASEAN Consensus, does not always translate into a clear set of practices and behaviours. Rather, the ASEAN Consensus shows, hegemonic projects through a set of legal instrument, that is to build a moral values to recognise the rights of migrant workers. This consensus is also belief to strengthen the political, economic and socio-cultural pillars of the ASEAN Community.From the Consensus, the protection of migrant workers "only covers migrant workers who are documented and those who become undocumented through no fault of their own" by the definition in Chapter 1 point 2. This instrument is try to create some of structural forms for the Member State, due to the ASEAN hegemonic project of producing the integration in the region.

According to Nayak and Suchland (2006), the hegemonic project is formed through systematic relation of power that specialize in knowledge, becoming and acting to several people who have experience and agendas in the community and political entities. Sath (Gozzi, 2017), says that the scope of responsibility within international institutions becomes very broad to be applied not only to emergencies but also to situations where initiatives can be taken to prevent the outbreak of hostilities and to deal with the aftermath. The dynamics in the protection of migrant workers expose the struggles and basic nature of politics in creating a political framework or category, following that proposed by Tobing (2017) which is the approach taken by political elites in the protection of migrant workers in the Region. All definitions of the protection of human rights, especially the protection of migrant workers are shaped by socio-political and legal discourses to give meaning in them by the actors. The protection of migrant workers can also be used as a domination of state interests.

The ASEAN consensus resolves certain issues and refines certain meanings and practices. According to Nayak and Suchland (2006), it should be remembered that hegemonic projects seek to create a certain meaning and existence. From here we can see how the protection of migrant workers as constituted in the ASEAN Consensus is used to legitimize the operation of the hegemonic project, to promote labor migration in achieving regional integration in the ASEAN Community.

The hegemonic project according to Wullweber (2018) must be articulated in various ways that can manipulate the subject, actor, and some relevant actions in the assumption that the implementation of the project is a condition for achieving an (imagined) common good. On the same hand, the hegemonic project, according to B. Jessop (2008) is a project to ensure or maintain the political, intellectual, and moral leadership of the dominant class. Forsythe (Gordon \& Berkovitch, 2007) says that leaders often call for discourse to advance real political interests, and not because they care about human rights living in other countries or even human rights for their people. In this case, the ASEAN Consensus, makes it possible for state leaders not to fully care about the rights of their people, in the specific to protect the rights of migrant workers, but there are other goals to be achieved. This is because ASEAN member countries are aware of the contributions made by migrant workers, as noted in the ASEAN Consensus: "recognizing the contribution of migrant workers to the societies and economies of both Receiving and Sending States of ASEAN". Therefore, the discourse of protection is used to the Member States economic development, as well as integration in the ASEAN Community.

\section{Conclusion}

The discourse on the protection of migrant workers is thus instrumental to the operations and existence of the hegemonic project of the integration of ASEAN in the sense of the ASEAN Community. 
The requirement to the protection of the migrant workers to increase economical and political benefit. Although the protection of migrant workers as in the ASEAN Consensus is deemed not sufficient to become the basis for solving problems faced by migrant workers in ASEAN, it is felt that this consensus is a good step in giving a moral burden to the Member States to protect the rights of migrant workers.

We hope that the evaluation of the discourses on the issue of migrant workers will continue, revealing what is actually intended in the discourse given by actors, be it the state and or organizations in shaping the point of view of migrant workers, especially in the ASEAN region.

\section{References}

Bockermann, K. (2020). The Role Of Human Rights In International Relations. Theoretical Implication And Networking Regarding Economic Sanctions. GRIN Verlag.

Cholewinski, R. (2013). Protection of the Human Rights of Migrant Workers and Members of their Families under the UN Migrant Workers Convention as a Tool to Enhance Development in the Country of Employment. Retrieved from https://www2.ohchr.org/english/bodies/cmw/docs/cholewinski.doc.

Cristol, J. (2019). Constructivism. $\quad$ Retrieved from https://www.oxfordbibliographies.com/view/document/obo-9780199743292/obo-97801997432920061.xml.

Dunne, T., \& Hanson, M. (2008). Human Rights in International Relations. New York: Oxford.

Fairclough, I., \& Fairclough, N. (2012). Political Discourse Analysis: A Method for Advanced Students. New York: Routledge.

Friedrichs, J. (2005). Global Governance as the Hegemonic Project of Transatlantic Civil Society. In M. Lederer, \& P. S. Müller, Criticizing Global Governance (pp. 45-68). New York: Palgrave Macmillan.

Gozzi, G. (2017). The "Discourse" of International Law and Humanitarian Intervention. An International Journal of Jurisprudence and Philosophy of Law, 30(2), 186-204.

Human Rights Working Group (HRWG) Indonesia. (2018). Migrant Worker's Rights in ASEAN Region: A Baseline Study. Jakarta: Human Rights Working Group (HRWG) Indonesia.

Isnarti, R. (2018). Humanitarian Intervention from Constructivism Perspective: Case Study of China Peace Keeping Operation in Darfur. AEGIS, 154-165.

Jackson, R., \& Sørensen, G. (2007). Social Constructivism. In R. Jackson, \& G. Sørensen, Introduction to International Relations: Theory and Approaches. New York: Oxford University Press Inc.

Nandyatama, R. W., Prabandari, A., \& Umar, A. R. (2014). Challenging State Hegemony: ASEAN, Human Rights Advocacy, and Non-Government Organisation in Indonesia. ASEAN Studies Center.

Solidaritas Perempuan. (2014). Situasi Kekerasan dan Pelanggaran Hak Buruh Migran Perempuan dan Keluarganya di Negara ASEAN.

Srinivas, S., \& Sivaraman, S. (2011). Regional Labour Migration in the Association of Southeast Asian Nations: Background and Context. Jakarta: ERIA . 
The ASEAN Secretariat. (2015). ASEAN Economic Community Blueprint. Jakarta: Public Outreach and Civil Society Division.

The ASEAN Secretariat. (2016). ASEAN Political-Security Community Blueprint 2025. Jakarta: Comminity Relations Division.

The ASEAN Secretariat. (2016). ASEAN Socio-Cultural Community Blueprint 2025. Jakarta: Community Relations Division.

Thuzar, M. (2017, November 16). "The ASEAN “Consensus” on Migrant Workers: Not Ideal But a Basis to Continue Working” . Retrieved from ISEAS - Yusof Ishak Institute: https://www.iseas.edu.sg/media/commentaries/the-asean-consensus-on-migrant-workers-not-idealbut-a-basis-to-continue-working-by-moe-thuzar/

Whisnant, C. (2012). Foucault \& Discourse.

Wullweber, J. (2018). Constructing Hegemony in Global Politics. A Discourse-Theoretical Approach to Political Analysis. Administrative Theory \& Praxis.

\section{Copyrights}

Copyright for this article is retained by the author(s), with first publication rights granted to the journal.

This is an open-access article distributed under the terms and conditions of the Creative Commons Attribution license (http://creativecommons.org/licenses/by/4.0/). 